Case Report

\title{
Unusual Presentation of Priapism Associated with Acute and Chronic Myeloid Leukemia in Two Patients: Emergency Management
}

\author{
Oumar Gaye $\mathbb{D}^{\mathrm{D}},{ }_{1}^{1}$ Ngor Mack Thiam, ${ }^{1}$ Ayun Cassell, ${ }^{2}$ Serigne Mourtalla Gueye, ${ }^{3}$ Yaya Sow, ${ }^{1}$ \\ Boubacar Fall, ${ }^{1}$ and Alain Khassim Ndoye ${ }^{1}$ \\ ${ }^{1}$ Urology-Andrology Department, Hôpital Aristide Le Dantec, Senegal \\ ${ }^{2}$ Urology-Andrology Department, Hôpital Général Idrissa Pouye, Senegal \\ ${ }^{3}$ Centre National de Transfusion Sanguine, Dakar, Senegal \\ Correspondence should be addressed to Oumar Gaye; oumargaye-uro@outlook.fr
}

Received 17 February 2020; Revised 1 June 2020; Accepted 20 June 2020; Published 13 August 2020

Academic Editor: Francesco M. Solivetti

Copyright (C) 2020 Oumar Gaye et al. This is an open access article distributed under the Creative Commons Attribution License, which permits unrestricted use, distribution, and reproduction in any medium, provided the original work is properly cited.

Priapism is a rare urological emergency. It is rarely a telltale sign of myeloid leukemia. We report two cases of acute myeloid leukemia in a child and chronic myeloid leukemia in a young adult presenting with priapism. Puncture irrigation of the corpora cavernosa followed by systemic treatment to lower the hyperviscosity of the blood due to leukemia provided optimal outcome. Prompt emergency management is required to lower the complication of erectile dysfunction.

\section{Introduction}

Priapism is defined as the persistence of a complete or partial erection beyond four hours, after orgasm/cessation or without any sexual stimulation.

There are three different types of priapism: high-flow priapism, ischemic priapism, and recurrent priapism [1]. Ischemic priapism is the most frequent and serious type requiring emergency management to avoid complications such as erectile dysfunction. [1]. In the United States, ischemic priapism presents more commonly with an incidence of up to 5.34 per 100,000 men per year [2].

The hematological disorder is responsible to $20 \%$ of priapism [3]. Priapism resulting from acute or chronic myeloid leukemia is unusual [4]. In adult patients with leukemia, the incidence of priapism is estimated to be approximately $5 \%$ [5] and $15 \%$ in the pediatric population [6].

Emergency management requires combined systemic treatment along with local treatment of the corpora cavernosa [7]. We report two clinical cases of priapism occurring with of myeloid leukemia received in the urological emergency department.

\section{Case 1}

A case of a 46-year-old male patient was consulted for a painful erection for 48 hours without any previous sexual stimulation, trauma, or medication intake.

Physical assessment revealed a male with good general condition, grade 1 splenomegaly, hepatomegaly with hepatic notch at $14 \mathrm{~cm}$, rigidity of the corpora cavernosa, and a flaccid glans penis.

The emergency laboratory workup showed Hemoglobin: $9.7 \mathrm{~g} / \mathrm{dl}$, Reds cells: $2920000 / \mathrm{mm}^{3}$, White Blood Cell: $526000 / \mathrm{mm}^{3}$, Platelets: $412000 / \mathrm{mm}^{3}$, Lactate Dehydrogenase: $1491 \mathrm{U} / \mathrm{I}$, Urea: $0.23 \mathrm{~g} / \mathrm{L}$, and Creatinine level: $7.8 \mathrm{mg} / \mathrm{L}$.

Blood smear (Figure 1) showed Myeloblast: 12\%, Promyelocytes: $85 \%$, Myelocytes: $11 \%$, and Eosinophil: $4 \%$.

The emergency management consisted of rehydration, an infusion of sodium bicarbonate, a puncture of the corpora 


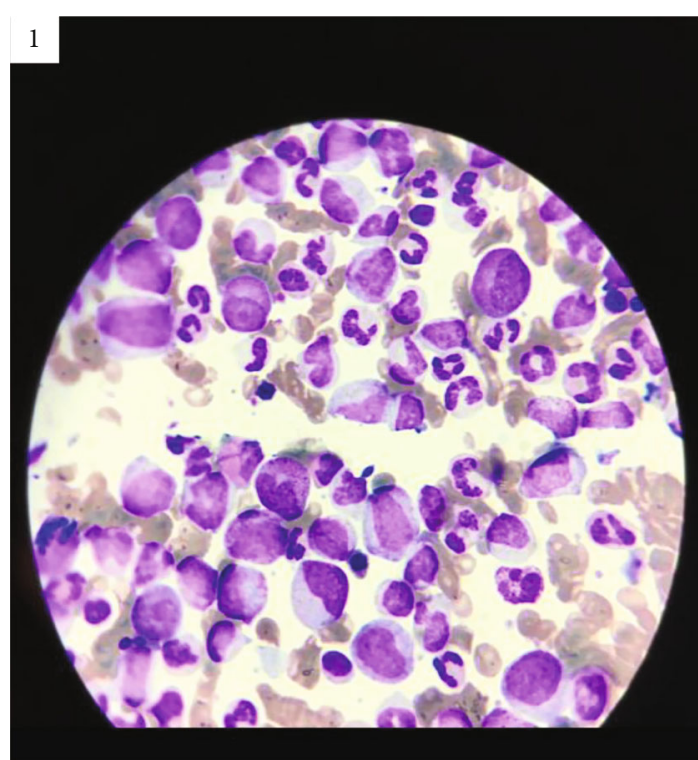

Figure 1: Blood smear showing myeloblast, promyelocytes, myelocytes, and eosinophil.

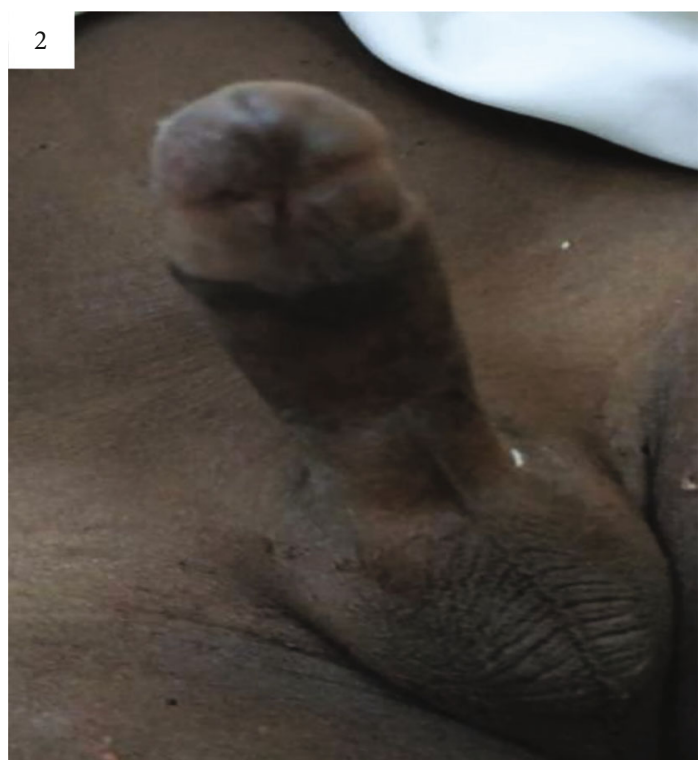

Figure 2: Rigidity of the corpora cavernosa and a flaccid glans penis.

cavernosa, injection of phenylephrine along with administration of hydroxycarbamide. Detumescence was achieved after 36 hours.

Subsequently, a myelogram showed bone marrow hyperplasia and a karyotype revealed a translocation between chromosomes 9 and 22 confirming the diagnosis of chronic myeloid leukemia. The patient was continued with doses of imatinib.

\section{Case 2}

A case of a 9-year-old child was seen in the emergency department for a sudden onset of a painful erection evolving

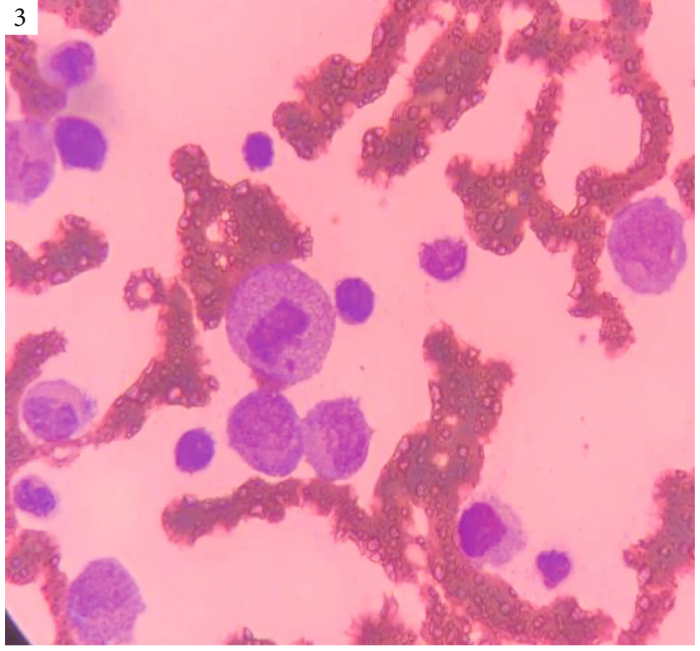

FIGURE 3: Bone marrow biopsy showing blast cell infiltration, leukemic infiltrate, mitoses, and presence of inflammatory cells.

for about 36 hours without any previous sexual stimulation, trauma, or medication intake.

The examination showed Pallor of the conjunctival mucosa, grade 1 splenomegaly, gingival enlargement, rigidity of the corpora cavernosa, and a flaccid glans penis (Figure 2).

The emergency laboratory workup: Hemoglobin: $3.4 \mathrm{~g} / \mathrm{dl}$, Reds cells: $1090000 / \mathrm{mm}^{3}$, White Blood Cell: $82000 / \mathrm{mm}^{3}$, Platelets: $81000 / \mathrm{mm}^{3}$, Neutrophils: $1 \%$ or $824 / \mathrm{mm}^{3}$, Eosinophils: $4 \%$ or $3296 / \mathrm{mm}^{3}$, Lymphocytes-h: $3 \%$ or $2472 / \mathrm{mm}^{3}$, Hematocrit: $11 \%$, Urea: $0.21 \mathrm{~g} / \mathrm{L}$ Creatinine level: $06 \mathrm{mg} / \mathrm{L}$, and Blood smear: Blasts: 92\%.

The emergency management consisted of penile skin refrigeration, rehydration, puncture of the corpora cavernosa with injection of phenylephrine, and induction of chemotherapy with vincristine and prednisolone, which achieved detumescence in 12 hours.

The bone marrow biopsy performed later confirmed an acute myeloid leukemia (Figure 3). Hemoglobin electrophoresis was performed and ruled out sickle cell disease.

\section{Discussion}

Priapism is a rare urological emergency. Ischemic priapism results from an obstruction of the venous blood and is manifested by a painful erection with rigidity of the corpora cavernosa and a flaccid glans penis [7]. It is the most urgent and frequent type requiring emergency care to prevent complications such as erectile dysfunction.

To date, less than 20 cases of priapism and chronic myeloid leukemia $[2,3,5,8-15]$ have been reported and 2 cases of priapism and acute lymphoblastic leukemia [16, 17] (Table 1).

In Senegal, sickle cell disease is responsible for the majority of priapism cases [18]. Leukemia is rarely complicated by priapism. When it occurs, it is most often caused by chronic myeloid leukemia and more rarely by acute lymphoid leukemia or acute myeloid leukemia [9].

Hyperleukocytosis is considered the underlying pathology of priapism in these instances. The main mechanism is 
Table 1: Literature review of priapism and leukemia from 2003 to 2020 using the PubMed database.

\begin{tabular}{|c|c|c|c|c|c|c|c|}
\hline Series & Age & Diagnosis & $\begin{array}{l}\text { Presenting } \\
\text { symptoms }\end{array}$ & $\begin{array}{c}\mathrm{WBC} \\
\text { cell } / \mathrm{mm}^{3}\end{array}$ & $\begin{array}{l}\text { Platelet } \\
\text { count } \\
\text { cell } / \mathrm{mm}^{3}\end{array}$ & Treatment of priapism and leukemia & Outcome \\
\hline $\begin{array}{l}\text { Becerra- } \\
\text { Pedraza } \\
\text { et al. [2] }\end{array}$ & 52 yrs & $\begin{array}{l}\text { Chronic } \\
\text { myeloid } \\
\text { leukemia }\end{array}$ & $\begin{array}{l}\text { Priapism for } \\
144 \text { hrs, fatigue, } \\
\text { pallor }\end{array}$ & 282000 & & $\begin{array}{l}\text { Corpora cavernosa drainage- } \\
\text { irrigation penile shunts. Dasatinib }\end{array}$ & $\begin{array}{l}\text { No ED on follow- } \\
\text { up }\end{array}$ \\
\hline $\begin{array}{l}\text { Hazra et al. } \\
{[3]}\end{array}$ & 14 yrs & $\begin{array}{l}\text { Chronic } \\
\text { myeloid } \\
\text { leukemia }\end{array}$ & $\begin{array}{l}\text { Priapism for } \\
24 \mathrm{hrs}\end{array}$ & 226900 & 310000 & $\begin{array}{l}\text { Cavernosal aspiration and } \\
\text { phenylephrine irrigation }\end{array}$ & $\begin{array}{l}\text { No recurrence at } \\
\text { 2-month follow- } \\
\text { up }\end{array}$ \\
\hline $\begin{array}{l}\text { Khan et al. } \\
{[5]}\end{array}$ & $16 \mathrm{yrs}$ & $\begin{array}{l}\text { Chronic } \\
\text { myeloid } \\
\text { leukemia }\end{array}$ & $\begin{array}{l}\text { Priapism for } \\
264 \mathrm{hrs}\end{array}$ & 614800 & 7090000 & $\begin{array}{l}\text { Glans-cavernosal shunt hydroxyurea } \\
\text { and allopurinol }\end{array}$ & $\begin{array}{l}\text { Achieved } \\
\text { detumescence. No } \\
\text { info on ED }\end{array}$ \\
\hline $\begin{array}{l}\text { Nerli et al. } \\
{[8]}\end{array}$ & $19 \mathrm{yrs}$ & $\begin{array}{l}\text { Chronic } \\
\text { myeloid } \\
\text { leukemia }\end{array}$ & $\begin{array}{l}\text { Priapism for } \\
24 \mathrm{hrs}\end{array}$ & 296800 & 936000 & $\begin{array}{l}\text { Corporal aspiration and } \\
\text { phenylephrine irrigation hydroxyurea } \\
\text { and imatinib }\end{array}$ & $\begin{array}{l}\text { Achieved } \\
\text { detumescence. No } \\
\text { info on ED }\end{array}$ \\
\hline $\begin{array}{l}\text { Minckler } \\
\text { et al. [9] }\end{array}$ & $18 \mathrm{yrs}$ & $\begin{array}{l}\text { Chronic } \\
\text { myeloid } \\
\text { leukemia }\end{array}$ & $\begin{array}{l}\text { Recurrent } \\
\text { priapism }\end{array}$ & $\begin{array}{c}5880 \\
000\end{array}$ & 1090000 & Hydroxyurea and imatinib & $\begin{array}{l}\text { No info on follow- } \\
\text { up }\end{array}$ \\
\hline $\begin{array}{l}\text { Chang et al. } \\
{[10]}\end{array}$ & $21 \mathrm{yrs}$ & $\begin{array}{l}\text { Chronic } \\
\text { myeloid } \\
\text { leukemia }\end{array}$ & $\begin{array}{l}\text { Priapism for } \\
19 \mathrm{hrs}\end{array}$ & 216800 & 1746000 & $\begin{array}{l}\text { Cavernosa aspiration and } \\
\text { epinephrine irrigation hydroxyurea } \\
\text { and interferon }\end{array}$ & $\begin{array}{l}\text { No ED on follow- } \\
\text { up }\end{array}$ \\
\hline $\begin{array}{l}\text { Qu et al. } \\
{[11]}\end{array}$ & $18 \mathrm{yrs}$ & $\begin{array}{l}\text { Chronic } \\
\text { myeloid } \\
\text { leukemia }\end{array}$ & $\begin{array}{l}\text { Priapism for } \\
72 \mathrm{hrs}\end{array}$ & 257000 & 5450000 & $\begin{array}{l}\text { Cavernosa-corpus spongiosum shunt, } \\
\text { imatinib }\end{array}$ & $\begin{array}{l}\text { No ED at 3-month } \\
\text { follow-up }\end{array}$ \\
\hline $\begin{array}{l}\text { Yoshida } \\
\text { et al. [12] }\end{array}$ & $29 \mathrm{yrs}$ & $\begin{array}{l}\text { Chronic } \\
\text { myeloid } \\
\text { leukemia }\end{array}$ & $\begin{array}{l}\text { Priapism for } \\
48 \mathrm{hrs}\end{array}$ & 263000 & & $\begin{array}{l}\text { Glans-cavernosal shunt hydroxyurea } \\
\text { and imatinib }\end{array}$ & $\begin{array}{l}\text { No ED at 5-month } \\
\text { follow-up }\end{array}$ \\
\hline Tazi [13] & 33 yrs & $\begin{array}{l}\text { Chronic } \\
\text { myeloid } \\
\text { leukemia }\end{array}$ & $\begin{array}{l}\text { Priapism for } \\
22 \mathrm{hrs}\end{array}$ & 400000 & 1200000 & $\begin{array}{l}\text { Cavernosa aspiration and } \\
\text { epinephrine irrigation }\end{array}$ & $\begin{array}{l}\text { No recurrence on } \\
\text { follow-up }\end{array}$ \\
\hline $\begin{array}{l}\text { Ponniah } \\
\text { et al. [14] }\end{array}$ & $19 \mathrm{yrs}$ & $\begin{array}{l}\text { Chronic } \\
\text { myeloid } \\
\text { leukemia }\end{array}$ & $\begin{array}{l}\text { Priapism for } \\
18 \mathrm{hrs}\end{array}$ & 513000 & & $\begin{array}{c}\text { Failed cavernosal aspiration }+ \\
\text { leukapheresis }\end{array}$ & $\begin{array}{l}\text { No ED on follow- } \\
\text { up }\end{array}$ \\
\hline $\begin{array}{l}\text { Ergenc et al. } \\
{[15]}\end{array}$ & $18 \mathrm{yrs}$ & $\begin{array}{l}\text { Chronic } \\
\text { myeloid } \\
\text { leukemia }\end{array}$ & $\begin{array}{l}\text { Priapism for } \\
72 \mathrm{hrs}\end{array}$ & 100000 & 1002000 & İmatinib, allopurinol + leukapheresis & $\begin{array}{l}\text { No ED at 6-month } \\
\text { follow-up }\end{array}$ \\
\hline $\begin{array}{l}\text { Gupta et al. } \\
{[16]}\end{array}$ & $10 \mathrm{yrs}$ & $\begin{array}{l}\text { Acute } \\
\text { lymphoblastic } \\
\text { leukemia }\end{array}$ & $\begin{array}{l}\text { Priapism, fever, } \\
\text { headache }\end{array}$ & 693000 & 40000 & $\begin{array}{c}\text { Corporal aspiration followed by } \\
\text { phenylephrine irrigation, allopurinol } \\
+ \text { steroids }\end{array}$ & $\begin{array}{l}\text { Died after } 48 \\
\text { hours }\end{array}$ \\
\hline $\begin{array}{l}\text { Güzelküçük } \\
\text { et al. [17] }\end{array}$ & 9 yrs & $\begin{array}{l}\text { Acute } \\
\text { lymphoblastic } \\
\text { leukemia }\end{array}$ & $\begin{array}{l}\text { Priapism for } \\
18 \mathrm{hrs}\end{array}$ & 583000 & 51000 & $\begin{array}{c}\text { Corporal aspiration followed by } \\
\text { hydroxyurea, allopurinol + } \\
\text { leukapheresis }\end{array}$ & $\begin{array}{c}\text { Achieved } \\
\text { detumescence }\end{array}$ \\
\hline
\end{tabular}

ED: erectile dysfunction; Hrs: hours; WBC: White Blood Cell; Yrs: years.

the aggregation of leukemia cells in the corpora cavernosa and the dorsal vein of the penis. Other accessory mechanisms are venous congestion of the corpora cavernosa secondary to mechanical pressure from the abdominal veins draining the spleen or infiltration of the sacral nerves or the central nervous system by leukemia cells [9].

Vadakan and Ortega described a case of priapism, which occurred from an acute lymphoid leukemia without hyperleukocytosis suggesting a disturbance of the central or peripheral nervous system [19]. Chang et al. have described priapism secondary to acute myeloid leukemia due to the direct penetration of the penis by leukemia cells [8]. As in most of the reports described [9-17], hyperleukocytosis was the most likely cause of priapism in the two cases of this report.

The American Urology Association [7] recommended combining systemic treatment of the organic cause with local treatment of the corpora cavernosa in cases of priapism secondary to leukemia. Systemic treatment is indicated for cytoreduction. It combines hydroxyurea with imatinib with or without leukapheresis to reduce hyperviscosity in chronic myeloid leukemia $[8,9,20,21]$ and chemotherapy in acute myeloid leukemia [22].

The local treatment at the level of the cavernous bodies involves a puncture evacuating the blood of the cavernous bodies along the lateral route at the penoscrotal or trans- 
glandular junction with an injection of alpha sympathomimetic agent. Amongst these agents, the use of etilefrine or phenylephrine has been favored because of their pure alpha-stimulating nature and better cardiac tolerance [21].

Other treatments such as radiotherapy of the penis, spinal anesthesia [23], irradiation of the spine [23, 24], the application of hot compresses [25], or penile refrigeration $[19,23]$ have been described with less satisfactory results.

The review showed that corporal aspiration/irrigation or a distal shunt was sufficient in achieving at least partial detumescence $[2,5,8]$. These procedures were followed by the treatment of the underlying leukemia with adequate hydration, hydroxyurea, imatinib, and leukapheresis [10-17]. The reports showed disease remission at a maximum 6-month follow-up with adequate erectile function.

\section{Conclusion}

Priapism is a usual presentation of myeloid leukemia and exceptionally rare association. A blood cell count showing hyperleukocytosis should suggest leukemia.

Emergent combination of systemic treatment with local treatment in the corpora cavernosa provides satisfactory results.

\section{Consent}

A written and signed consent was received from the patient for publication of this report.

\section{Conflicts of Interest}

There is no conflict of interest to declare.

\section{Acknowledgments}

Special thanks are due to the Urology-andrology department, Hôpital Aristide Le Dantec (Sénégal).

\section{References}

[1] S. Droupy and F. Giuliano, "Priapismes," Progrès en Urologie, vol. 23, no. 9, pp. 638-646, 2013.

[2] L. C. Becerra-Pedraza, L. E. Jiménez-Martínez, I. Peña-Morfin, R. Nava-Esquivel, and J. A. Villegas-Martínez, "Priapism as the initial sign in hematologic disease: case report and literature review," International Journal of Surgery Case Reports, vol. 43, pp. 13-17, 2018.

[3] S. P. Hazra, V. Priyadarshi, D. Gogoi, P. K. Sharma, D. K. Pal, and S. C. Chakraborty, "Pediatric priapism: a rare first manifestation of leukemia," APSP Journal of Case Reports, vol. 4, no. 3, p. 39, 2013.

[4] R. Rodgers, Z. Latif, and M. Copland, "How I manage priapism in chronic myeloid leukaemia patients," British Journal of Haematology, vol. 158, no. 2, pp. 155-164, 2012.

[5] A. Khan, I. Shafiq, M. H. Shah, S. Khan, G. Shahid, and M. Arabdin, "Chronic myeloid leukaemia presenting as priapism: a case report from Khyber Pakhtunkhwa," The Journal of the Pakistan Medical Association, vol. 68, no. 6, pp. 942-944, 2018.
[6] N. Paladino, D. Roldán, and M. S. Caram, "Priapismo en pediatría: presentación inicial de una leucemia mieloide crónica," Archivos Argentinos de Pediatría, vol. 109, no. 5, pp. e104-e108, 2011.

[7] D. K. Montague, J. Jarow, G. A. Broderick et al., "American Urological Association guideline on the management of priapism," The Journal of Urology, vol. 170, 4 Part 1, pp. 13181324, 2003.

[8] R. B. Nerli, P. V. Magdum, S. C. Hiremath et al., "Priapism - a rare presentation in chronic myeloid leukemia: case report," Urology Case Reports, vol. 4, no. 4, pp. 8-10, 2016.

[9] M. R. Minckler, E. Conser, J. J. Figueroa, A. J. Scott, J. Gaither, and R. Amini, "The semantics of priapism and the first sign of chronic myeloid leukemia," Case Reports in Emergency Medicine, vol. 2017, Article ID 2656203, 3 pages, 2017.

[10] M. W. Chang, C. C. Tang, and S. S. Chang, "Priapism a rare presentation in chronic myeloid leukemia: case report and review of the literature," Chang Gung Medical Journal, vol. 26, no. 4, pp. 288-292, 2003.

[11] M. Qu, X. Lu, L. Wang, Z. Liu, Y. Sun, and X. Gao, “Priapism secondary to chronic myeloid leukemia treated by a surgical cavernosa-corpus spongiosum shunt: case report," Asian Journal of Urology, vol. 6, no. 4, pp. 373-376, 2019.

[12] K. Yoshida, H. Kinoshita, H. Taniguti et al., "Priapism complicated by chronic myelogenous leukemia (CML); a case report," Acta Urologica Japonica, vol. 53, no. 5, pp. 323-325, 2007.

[13] I. Tazi, "Priapism as the first manifestation of chronic myeloid leukemia," Annals of Saudi Medicine, vol. 29, no. 5, p. 412, 2009.

[14] A. Ponniah, C. T. Brown, and P. Taylor, "Priapism secondary to leukemia: effective management with prompt leukapheresis," International Journal of Urology, vol. 11, no. 9, pp. 809810, 2004.

[15] C. Varım, C. Karacaer, D. Çekdemir, and H. Ergenc, "Chronic myeloid leukemia presented with priapism: effective management with prompt leukapheresis," Nigerian Journal of Clinical Practice, vol. 18, no. 6, pp. 828-830, 2015.

[16] G. Gupta, D. Kumar, and M. Trivedi, "Acute lymphoblastic leukemia in a child presenting primarily with priapism," Journal of Indian Association of Pediatric Surgeons, vol. 25, no. 1, pp. 52-54, 2020.

[17] Z. Güzelküçük, D. Kaçar, R. Demir, M. Kürtül, H. N. Yaralı, and N. Y. Özbek, "Priapism: a rare presentation of precursor B-cell acute lymphoblastic leukemia," The Turkish Journal of Pediatrics, vol. 61, no. 2, pp. 311-312, 2019.

[18] C. Sylla, M. Ba, A. Ndoye et al., "Penile emergencies," Annales d'Urologie, vol. 34, no. 3, pp. 203-207, 2000.

[19] V. V. Vadakan and J. ORTEGA, "Priapism in acute lymphoblastic leukemia," Cancer, vol. 30, no. 2, pp. 373-375, 1972.

[20] B. D. Adams, R. Baker, J. A. Lopez, and S. Spencer, "Myeloproliferative disorders and the hyperviscosity syndrome," Emergency Medicine Clinics of North America, vol. 27, no. 3, pp. 459-476, 2009.

[21] T. Jameel and K. Mehmood, "Priapism - an unusual presentation in chronic myeloid leukaemia: case report and review of the literature," Biomédica, vol. 25, pp. 197-199, 2009.

[22] A. L. Burnett and T. J. Bivalacqua, "Priapism: new concepts in medical and surgical management," The Urologic Clinics of North America, vol. 38, no. 2, pp. 185-194, 2011. 
[23] D. A. Grace and C. C. Winter, "Priapism an appraisal of management of twenty-three patients," The Journal of Urology, vol. 99, no. 3, pp. 301-310, 1968.

[24] R. G. Graw Jr., R. T. Skeel, and P. P. Carbone, "Priapism in a child with chronic granulocytic leukemia," The Journal of Pediatrics, vol. 74, no. 5, pp. 788-790, 1969.

[25] G. Maciotta, "Priapism as a symptom of leukemic myelosis in a 10 year old boy," Pediatria (Bucur), vol. 42, pp. 1093-1094, 1934. 